DOI: $10.1515 /$ pts-2017-0020

APPLIED PHYSICS

\title{
THE ANALYSIS OF ELECTRICAL ENERGY CONSUMPTION OF THE IMPACT SCREWDRIVER DURING ASSEMBLY OF FIXED THREADED JOINTS
}

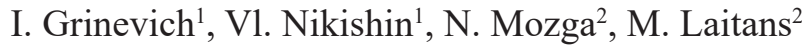 \\ ${ }^{1}$ Riga Technical University, Daugavpils Branch, \\ 90 Smilshu Str., Daugavpils, LV-5410, LATVIA, \\ Ivans.Grinevics@rtu.lv, Nikis@df.rtu.lv \\ ${ }^{2}$ Riga Technical University, \\ 6 Ezermalas Str., Riga, LV-1006, LATVIA, \\ Natalija.Mozga@rtu.lv
}

The paper deals with the possibilities of reducing the consumption of electrical energy of the impact screwdriver during the assembly of fixed threaded joints. The recommendations related to a decrease in electrical energy consumption would allow reducing product costs but so far there have been no such recommendations from the producers of the tool as to the effective operating regimes of the impact screwdrivers in relation to electrical energy consumption and necessary tightening moment of the nut.

The aim of the study is to find out the economical operating mode of the electrical impact screwdriver when assembling fixed threaded joints. By varying the set speed of the rotor head and working time of the impact mechanism, there is an opportunity to determine electrical energy consumption of the tool for the given tightening moment.

The results of the experiment show that at the same tightening moment obtained the electrical energy consumption of the impact screwdriver is less at a higher starting set speed of the rotor head but shorter operating time of the impact mechanism than at a lower speed of the rotor head and longer operating time of the impact mechanism.

Keywords: assembly process, electric energy consumption, impact screwdriver, threaded joints

\section{INTRODUCTION}

Electrical impact screwdrivers have experienced an extensive application in the process of assembling fixed threaded joints. Impact screwdrivers have a whole set of advantages over similar hydraulic or pneumatic tools, one of which is the 
ability to adjust the rotational frequency of a chuck, a relatively low weight, as well as their efficiency. The tools of this group are used in various technical fields, including automobile production, heavy industry, chemical industry, and others. Among the main technical parameters of the electrical impact screwdriver the following can be mentioned: the power, the number of RPM, and the maximum torque. Impact screwdrivers differ from ordinary (non-impact) analogues with their greater reached tightening moment with less output in the case of the tool. Such an effect is reached because the nut or the head of the screw is under the influence of not permanent attractive force but of the whole set of powerful, but relatively short impacts that are directed towards the tangent against the head of the screw. If the tool changes the tightening regime onto the impact-tightening regime, the rotational frequency of the rotary head decreases dramatically, though the resulting moment increases and the total value is the same as the sum of a single moment of each impact and it can reach up to $1000 \mathrm{Nm}$ or even a higher value [1].

On the basis of the literature survey it has been concluded that the reduction of the energy consumption of electric motor is quite a topical problem, which receives much attention. Different studies have been performed in connection with the increase in the efficiency coefficient of electric motor [2]. Certain studies are known in which the load mode selection of an electric motor is analysed [3], [4]. The dependence of tightening moment on the tension, steering angle and other parameters is also researched [5]. However, there are no studies which investigate the reduction of electric power consumption using the working tool in the working process and changing operating modes when assembling fixed threaded joints. The manufacturer's instructions attached [6] also do not have any recommendations for the most economical regimes of an impact screwdriver that acquire the necessary tightening moment. It is possible to determine the working regimes of an impact screwdriver theoretically knowing the initial data of the electric motor, parameters of the gearbox and the load of the motor [7], [8]. However, the calculations are rather complicated and the sheet of the initial data for the electric motor is not always easily obtained.

The research helps draw manufacturer's attention to the electrical energy consumption possibilities during the operating mode of the tool, by selecting the most economical working regime. Selection of uneconomical operation mode can significantly increase power consumption and reduce the lifetime of the instrument, which in turn leads to an increase in product costs.

\section{THE MATERIALS AND METHODS APPLIED IN THE RESEARCH}

The created equipment (see Fig. 1a), which allows determining electrical energy consumption of the screwdriver at various working regimes, consists of an electric impact screwdriver Bosch GDS 18 E fixed to the moving part of the stand 2. The stand is fixed to the metal plate 10 with the dimensions $300 \times 450 \times 40 \mathrm{~mm}$, which, in its turn, is mounted to the non-moving base. Screw tongs 7 are fixed to the base of the stand to fix two metal plates 6 with the dimensions of $90 \times 85 \times 12 \mathrm{~mm}$ and bolts with the help of L-type cantilever. Bolts M16 with the length of $40 \mathrm{~mm}$ and strength of 10.9 according to DIN 933 standard have been selected for the experiment. 
The electric impact screwdriver Bosch GDS $18 \mathrm{E}$ has been connected to the network with the help of the controller 9 , which is operated from the computer. The impact screwdriver is moved vertically by the handle 3. Dynamometric key Stahlwille Manoskop 730D/20 11 is used to determine the tightening moment after the moment of unscrewing. To determine the power, the USB oscilloscope (PicoScope 2205) 5 has been applied. The turns of the rotary head have been measured using the manual tachometer ALLURIS 8.

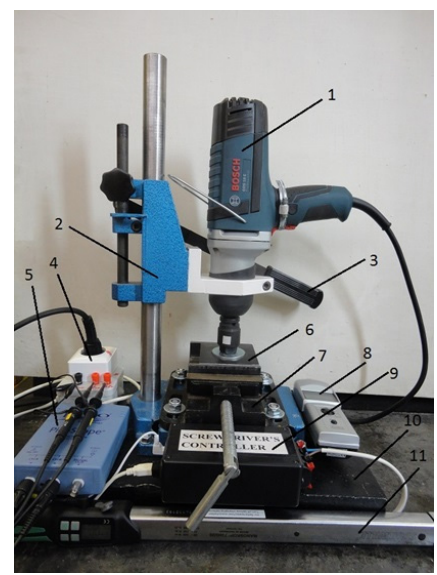

a)

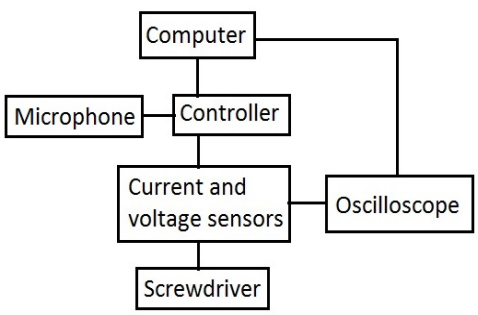

b)

Fig. 1. Measuring equipment:

a) image of the experimental equipment; b) block scheme of the equipment 1 - impact screwdriver; 2 - moving part of the stand; 3 - handle; 4 - power unit; 5 - USB oscillograph; 6 - metal plates; 7 - screw tongs; 8 - manual tachometer; 9 - controller; 10 - metal plate; 11 - dynamometric key.

The equipment consists of the controller, in which corresponding software has been installed to secure its operation. The controller has a microphone attached to register the start of the operation of the impact mechanism. There is a built-in relay in the controller for connecting the impact screwdriver to the network and disconnecting from it. The controller is connected to the computer. The computer has special software that allows changing the working time of the impact mechanism, installing the timer, which comes into operation from the increasing sound level (see Fig. 2). To register the current and voltage, the USB oscilloscope has been used, which receives the signal from the current and voltage transmitters. A resistor with resistance of $0.05 \Omega$ has been used as a current transmitter. A voltage splitter consisting of two resistors has been used as a voltage transmitter. A voltage splitter is necessary because the oscilloscope is able to work with the voltage up to 20V. Having processed the obtained voltage in the working environment of Picoscope software, a scheme of the consumed energy has been received, on the basis of which the amount of the consumed electrical energy has been calculated. The screwdriver has been operated with the help of the relay, by means of which it is plugged to the AC network, which is installed in the controller. The initial turns of the rotary head of the impact screwdriver have been set with the help of the controlling button 
determining them by the manual tachometer. At each set value of the turn and working time of the corresponding impact mechanism there have been 10 measurements taken (in total 90 measurements).

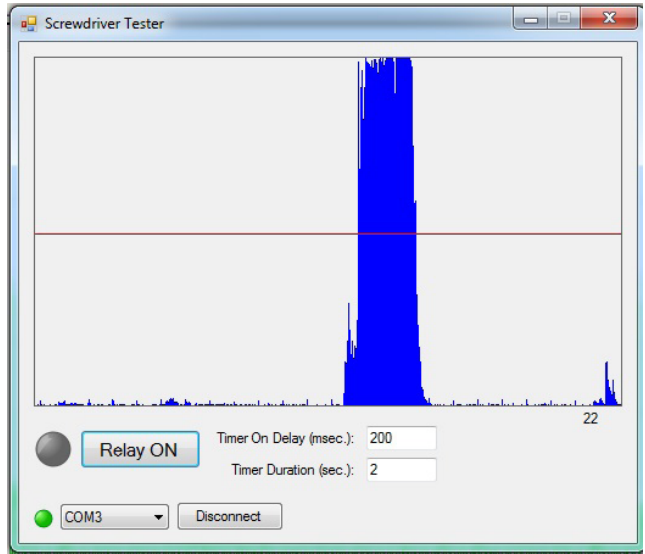

Fig. 2. The interface of the controlling block (horizontal red line - the sound level of the timer operation).

The signal in the Picoscope 6 software environment has been taken with $2 \cdot 10^{6}$ readouts per second and 8 bit resolution. The second channel voltage in the oscilloscope software PicoScope 6 has been recalculated in the equivalent of current, which has been consumed by the electric motor of the impact screwdriver. In Picoscope 6 software, a chart has been made displaying the product of current and voltage, i.e., the corresponding power. Picoscope 6 environment (Fig. 3) allows determining the average power value in the necessary time interval by multiplying discretization points (voltage and current) in the corresponding time moments. Thus, there has been the consumed power for screwing the nut determined. The peaks in the power graph are connected with the rotational speed adjustment characteristics of the impact screwdriver. The current peak in the impact screwdriver appears in the moment when the control element is opened. Due to this fact, one can see the peaks in the power graph.

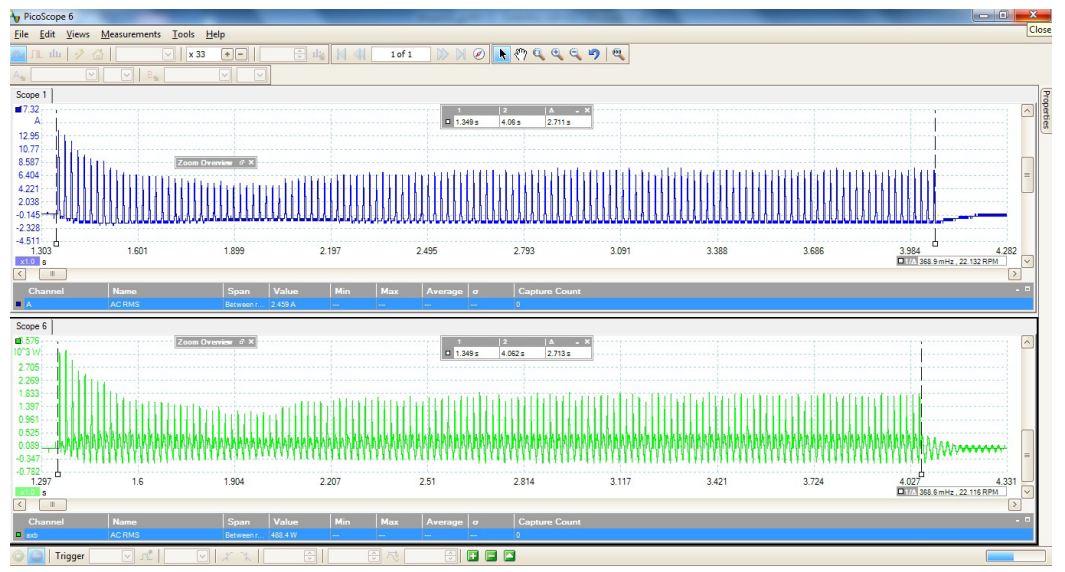

Fig. 3. Working environment of Picoscope 6. 
Changing the initial set turns of the rotary head $(720,960,1200)$ and the working time of the impact mechanism allowed determining the consumption of the electrical energy of the impact screwdriver and the tightening moment of the screw (see Table 1, Fig. 4 and Fig. 5). During the experiment, the difference in the value of electrical energy consumption at the selected measurement combinations did not exceed $10 \%$, but the difference in the values of nut tightening moment in singular modes reached almost $30 \%$. Despite it, the results of the experiments gave us some coherences of nut tightening moment and electrical energy consumption of the impact screwdriver.

Table 1

Electrical Energy Consumption of the Impact Screwdriver during Assembling Fixed Threaded Joints Depending on the Selected and Initially Set Turns of the Rotary Head and Working Time of the Impact Mechanism

\begin{tabular}{|l|c|c|c|}
\hline $\begin{array}{l}\text { Turns of the } \\
\text { rotary head } \\
\mathrm{n} ; \mathrm{min}^{-1}\end{array}$ & $\begin{array}{c}\text { Operating time of the } \\
\text { impact mechanism, } \\
\text { timp.; s }\end{array}$ & $\begin{array}{c}\text { Total electrical energy con- } \\
\text { sumption (average value from } \\
\text { 10 measurements) } \\
\text { E; J }\end{array}$ & $\begin{array}{c}\text { Average tightening } \\
\text { moment (from } \\
\text { 10 measurements) } \\
\text { M, N·m }\end{array}$ \\
\hline \multirow{3}{*}{720} & 0.5 & 568 & 22 \\
\cline { 2 - 4 } & 2.0 & 1296 & 47 \\
\hline \multirow{3}{*}{960} & 3.5 & 1918 & 75 \\
\cline { 2 - 4 } & 0.5 & 584 & 54 \\
\hline \multirow{3}{*}{1200} & 2.0 & 1329 & 98 \\
\cline { 2 - 4 } & 3.5 & 2082 & 127 \\
\cline { 2 - 4 } & 0.5 & 678 & 131 \\
\hline
\end{tabular}

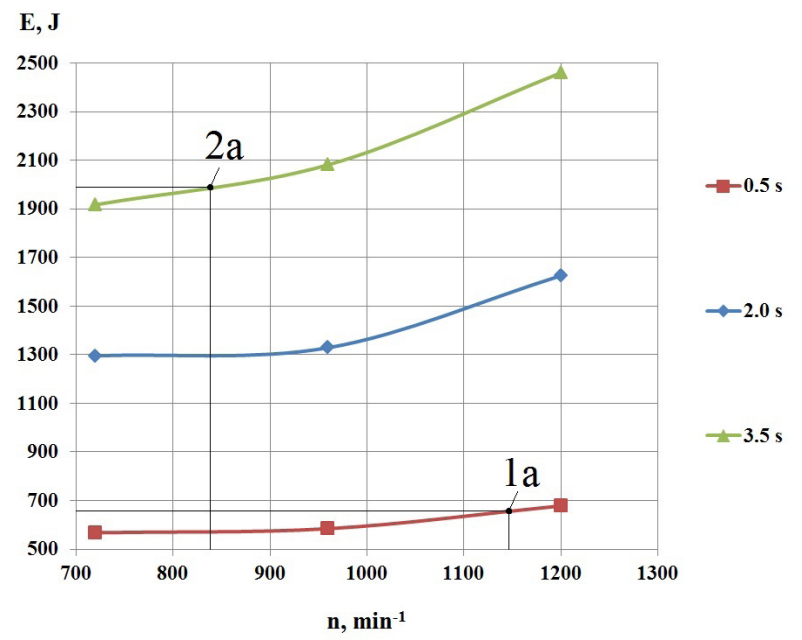

Fig. 4. Electrical energy consumption depending on selection of the initially set turns of the rotary head and fixed working time of the impact mechanism. 


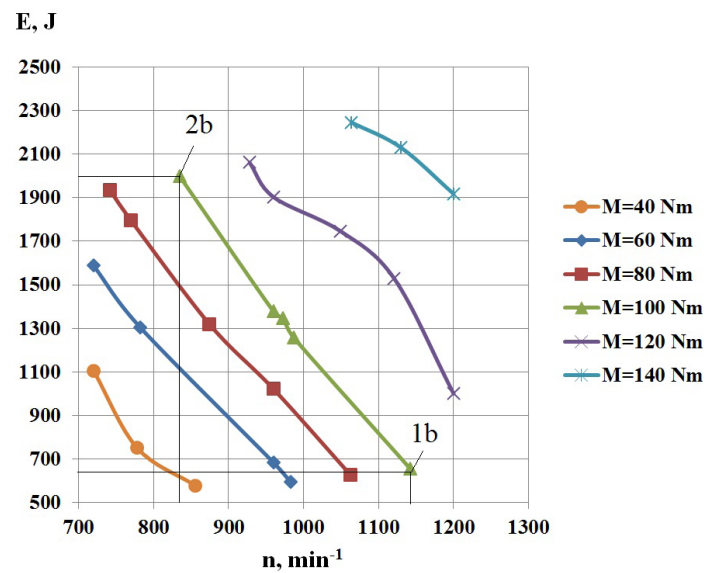

Fig. 5. Tightening moment of the screw depending on the value of initially set turns of the rotary head and electrical energy consumption (the graph is built using an orthogonal compositional planning method [9]).

\section{RESULTS}

Analysing Fig. 4, one can see that the electrical energy consumption for the given impact screwdriver ranges from $238 \ldots 263 \%$ depending on the working time of the impact mechanism $(0.5,2.0$ or $3.5 \mathrm{~s})$ and at constant initially set turns of the rotary head. However, dependence on the initially set turns of the rotary head $\left(720,960\right.$ or $\left.1200 \mathrm{~min}^{-1}\right)$ and constant working time of the impact mechanism is $19 \ldots 28 \%$. Thus, assembling fixed threaded joints the most economical operating mode for the impact screwdriver is at a higher starting set speed of the rotor head but a shorter operating time of the impact mechanism than at a lower speed of the rotor head and longer operating time of the impact mechanism. For example, if one chooses $100 \mathrm{~N}^{*} \mathrm{~m}$ high value of tightening moment for bolt M16 it can be implemented by setting the speed of the rotor head of $1142 \mathrm{rpm}$ and $0.5 \mathrm{~s}$ for the impact mechanism operation period (Fig. 5, point 1b). The same can be achieved by setting the speed of the rotor head of $835 \mathrm{rpm}$ and $3.5 \mathrm{~s}$ for the impact mechanism operation period (Fig. 5, point 2b). The first assembly mode is more effective considering electrical energy consumption where electrical power consumption is only $656 \mathrm{~J}$ (Fig. 4, point 1a) instead of $1997 \mathrm{~J}$ (Fig. 4, point 2a).

\section{CONCLUSIONS}

Such an algorithm of the method could be applied to any kind of impact screwdrivers. Difference in electrical energy consumption at the same tightening moment between one and the other assembly variant (at a higher starting set speed of the rotor head but a shorter operating time of the impact mechanism or at a lower speed of the rotor head and longer operating time of the impact mechanism) will be higher at greater difference in the operating time of the impact mechanism. 
At a lower rotational speed of an electric motor, it operates in the mode in which it develops lower torque; therefore, it is not possible to obtain a high tightening moment.

It has been concluded that setting the precise working time of an impact mechanism with the help of the controller (avoiding unfavourable swing from the operator's reaction) as well as setting the initial turns of the rotary head of an impact screwdriver cannot ensure a precise attraction moment of a nut. This can be explained by the fact that the attraction process takes place within a very short period of time.

Rotational speed settings are required in order to get different tightening moments. Although at a maximum rotational speed the device efficiency is the highest, it is not possible to achieve tightening moments less than $115 \mathrm{Nm}$.

\section{ACKNOWLEDGEMENTS}

The research has been supported by Riga Technical University through the Scientific Research Project Competition for Young Researchers No. ZP-2013/12.

\section{REFERENCES}

1. Mayer, P. (2010, December 27). Do I Really Need an Impact Driver? Retrieved 16 November 2016, from https:/www.wwgoa.com/article/do-i-really-need-an-impact-driver/ ?nabc $=0 \&$ nabe $=5597362638815232: 2 \& u t m \_$referrer $=$https $\% 3 \mathrm{~A} \% 2 \mathrm{~F} \% 2 \mathrm{Fwww}$.google. $1 \mathrm{v} \% 2 \mathrm{~F}$

2. Nozawa, T. (2009, April 3). [JSAP] Tokai University Unveils 100W DC Motor with 96\% Efficiency. Retrieved 16 November 2016, from http://techon.nikkeibp.co.jp/english/ NEWS_EN/20090403/168295/

3. McCoy, G. A., \& Douglass, J.G. (1997). Energy Management for Motor-Driven Systems. Cooperative Extension Energy Program Report. US: Washington State University.

4. von Jouanne, A., Wallace, A., Douglass, J., Wohlgemuth, C., \& Wainwright, G. (1997). A laboratory assessment of in-service motor efficiency testing methods. In IEEE International Electric Machines and Drives Conference. Milwaukee, WI.

5. PCB Load \& Torque Division. Fastener Testing. Retrieved 20 November 2016, from http://www.pcb.com/FasteningTechnology/FastenerTest

6. Robert Bosch GmbH. GDS 18 E Professional. Power Tools Division. Retrieved 20 November 2016, from

7. www.tooled-up.com/artwork/ProdPDF/Bosch-gds-18-e-professional.pdf

8. Theodore, W. (2006). Electrical Machines, Drives and Power Systems, 6/E. Sperika Enterprises Ltd. Prentice Hall.

9. Maxon DC Motor and Maxon EC Motor. Key information. Retrieved 20 November 2016, from http://www.maxonmotor.com/medias/sys_master/8802918268958/maxonFormelsammlung-e.pdf?attachment=true

10. Vuchkov, I.N., \& Boyadjieva, L.N. (2001). Quality Improvement with Design of Experiments: A Response Surface Approach. Dordrecht: Kluwer Academic Publishers. 


\section{TRIECIENSKRŪVGRIEŽA ELEKTROENERG̣IJAS PATĒRIN̦A ANALĪZE, VEICOT NEKUSTİGA VĪTN̦U SAVIENOJUMA SALIKŠANU}

I. Griṇēvičs, V. Nikišins, N. Mozga, M. Laitāns

Kopsavilkums

Dotajā rakstā uzmanība tiek pievērsta triecienskrūvgrieža elektroenergíjas patēriņa samazināšanas iespējām, veicot nekustīgu vītnu savienojumu salikšanu. Izveidota iekārta ar kuras palīdzību, mainot triecienskrūvgrieža rotorgalvinas sākumā iestatītos apgriezienus un triecienmehānisma darba laiku, tika noteikts elektroenerğijas patēriņ̌š. Eksperimenta rezultāti l̦auj izprast ekonomiskos triecienskrūvgrieža darba režīmus un parāda zināmas sakarības, pamatojoties uz kurām, tika izveidotas svarīgas rekomendācijas.

19.12.2016. 